\title{
Friction and Wear Properties of Automobile Brake Linings Containing Borax Powder with Different Grain Sizes
}

\author{
İlker Sugözü ${ }^{1}$ and Banu Sugözü̈ ${ }^{*}$
}

0000-0001-8340-8121, 0000-0002-7798-2677

${ }^{1}$ Mechanical Engineering Department, Faculty of Engineering, Mersin University, Mersin, 33343, Turkey

\begin{abstract}
Borax which is an important boron compound, a mineral, and a salt of boric acid, is used as a fire retardant and insulating material. The most important reaction in automobile brake systems is heat generation from friction. The heat generated at the interface of disc and lining may cause deformation of the materials forming the lining. Therefore, phenomena such as lining wear and brake fade may be occurred. The aim of this study is to reveal the positive effects of borax additive on lining and experimentally examine the effect of grain size of borax on tribological properties. Lining is produced by mixing more than one powder materials and pressing cold and hot. The size and homogeneous mixture of powder materials affect the braking performance. In this study, the effect of using nano and micro sized borax with the same content on the lining performance was investigated. The produced linings were tested on pin-on disc tester. Wear, hardness and density tests were performed. The change in the friction coefficient was observed due to the temperature increase. The friction coefficient of the nano-containing lining showed a more stable result depending on the temperature.
\end{abstract}

Keywords: Brake lining, Borax, Tribology
Research Article

https://doi.org/10.30939/ijastech..924897

$\begin{array}{ll}\text { Received } & 21.04 .2021 \\ \text { Revised } & 22.05 .2021 \\ \text { Accepted } & 08.07 .2021\end{array}$

* Corresponding author

Banu Sugözü

banusugozu@mersin.edu.tr

Address: Mechanical Engineering Department, Faculty of Engineering, Mersin University, Mersin, Turkey

Tel: +903122028653

\section{Introduction}

Brake linings are created by combining materials with different properties. Material rates and sizes affect the performance of the lining. The proportions of the materials to be used in the lining should be chosen very well. In addition, the dimensions of the materials to be used in the lining are very important for a homogeneous mixture. Brake lining composites; are multi-component composites containing binder materials, fibers (reinforcement elements), solid lubricants, friction modifiers, abrasives and fillers [1].

When determining the friction material, high friction coefficient and good wear resistance are the desired properties. However, friction materials must maintain a constant coefficient of friction under difficult conditions such as high temperatures. In addition, it is desired to form a good friction pair, not damage the counter material, and exhibit a stable and high friction coefficient under difficult thermal and mechanical effects [2,3].

Friction adjusting additives are substances that change the friction coefficient. These can be grouped as abrasive and non-abrasive. Abrasive materials such as powdered alumina increase the friction coefficient, while solid lubricants such as graphite are components that are added to bring the friction coefficient to the desired level. Friction adjusters are the most widely varied component type.

Raw and refined borates are used in ceramic glazes. Borates reduce thermal expansion and give resistance and durability to the ceramics. Addition of borates increases the mechanical strength and resistance to thermal shocks. Various borax formulations can also be used as flame retardants [4].

Başar et al. [5] demonstrated that the use of boron derivatives in automotive brake linings creates resistance to abrasion in the development of new brake linings, and that the friction coefficient becomes smooth when boric acid and borax are used together with copper powder.

Akıncıoğlu et al. [6-8] produced brake linings with boron oxide and examined their tribological properties. As a result, they reported the positive effect of boron oxide additive on brake linings.

In a study conducted on the use of borax in brake lining materials [4], it was stated that the use of $12 \%$ borax by mass in the lining content improved the wear and friction properties of the lining.

In this study, the effect of using boron minerals borax on the tribological properties of nano and micro dimensions in brake lin- 
ing friction materials was investigated. For this purpose, two different linings containing $10 \%$ nano and micro borax by mass were produced by powder metallurgy method. Tribological properties were examined to determine the braking performance of the produced linings.

\section{Materials and Methods}

Asbestos-free reinforcement materials have been selected in the production of the linings. The mass ratio was taken as a basis in determining the material rates during production. The powder contents that make up the lining sample are given in Table 1. The borax ratio of the samples produced is balanced with barite, which is the filling material. It is coded as MB10 and NB10 according to the amount of micro and nano borax.

Table 1. Lining content produced.

\begin{tabular}{c|c|c|c}
\hline \multirow{2}{*}{ Constituent } & \multirow{2}{*}{$\begin{array}{c}\text { Material group and } \\
\text { task }\end{array}$} & \multicolumn{2}{|c}{ Weight percent (\%) } \\
\cline { 3 - 4 } & BB10 & NB10 \\
\hline Phenolic resin & Binder & 20 & 20 \\
\hline Steel fibre & Reinforcement & 8 & 8 \\
\hline Cashew dust & Friction modifiers & 10 & 10 \\
\hline Brass particles & Heat conductor & 5 & 5 \\
\hline Graphite & Solid lubricant & 4 & 4 \\
\hline Copper particles & Heat conductor & 8 & 8 \\
\hline Alumina & Abrasive & 5 & 5 \\
\hline Borax & Heat conductor & 10 & 10 \\
\hline Barite & Space filler & 30 & 30 \\
\hline
\end{tabular}

Before starting production, the powder materials were weighed with a scale with a sensitivity of $0.001 \mathrm{~g}$. The mixtures prepared in the specified ratios were mixed in the mixer at $120 \mathrm{rpm}$ for 10 minutes to ensure homogeneity. The prepared mixture was transferred to a mold with a diameter of $25.4 \mathrm{~mm}$ and kept under $8 \mathrm{MPa}$ pressure for 2 minutes and preformed. Then the samples were subjected to hot pressing at $10 \mathrm{MPa}$ pressure and $150^{\circ} \mathrm{C}$ for 10 minutes. Photos of the produced samples are given in Figure 1.

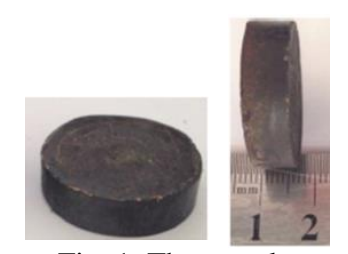

Fig. 1. The samples

A test set that can transfer the friction coefficient, brake force, hydraulic system pressure, lining surface temperature values given in Figure 2 to the computer environment during the experiment was used in determining the friction coefficient and time characteristics of the samples whose production was completed. A load cell was used to measure the friction force between the lining and the brake disc during rotation in the experimental setup. Thus, this rotational force was measured electronically, taking into account the desire of the lining to rotate together with the disc due to the friction force generated by the pressure applied to the brake lining during the rotation of the disc. There is a speed adjuster in order to use the brake disc in the experimental setup at the desired speed and speed. In order for the experiments to be carried out in accordance with the standards, a non-contact (IR) thermometer that can receive data every second and can operate between -50 and $1000{ }^{\circ} \mathrm{C}$ was placed in the test setup to determine the disc surface temperature. A brake disc made of gray cast iron with a hardness of $116 \mathrm{HB}$ (41.86 HRA) and a diameter of $280 \mathrm{~mm}$ was used in the test processes [9].

The linings produced were placed in the test device with the help of lugs and operated at a speed of $3 \mathrm{~m} / \mathrm{s}$ under $0.7 \mathrm{MPa}$ pressure until $95 \%$ of the sample surface touched the disc surface in order to ensure that the friction surfaces coincide. The tests were carried out at $1.05 \mathrm{MPa}$ lining surface pressure and $6 \mathrm{~m} / \mathrm{s}$ speed. The friction coefficient and time values taken during the tests are the arithmetic mean of the values taken from three samples produced with the same mixture and properties. For each sample, the coeffi-

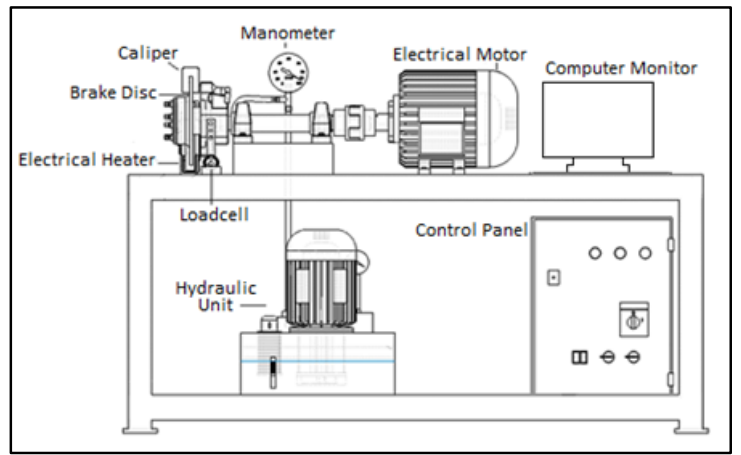

cient of friction was recorded for approximately 700 seconds at 1 second intervals under $1.05 \mathrm{MPa}$ pressure at $6 \mathrm{~m} / \mathrm{s}$.

Fig. 2. Brake lining friction test equipment [9]

The specific wear rate on the linings was calculated according to TSE 555 [10]. Detailed information is given in the author's work [9].

A steel ball tip with a diameter of $2.5 \mathrm{~mm}$ was used as the puncture tip in the hardness measurement processes. The applied load is taken as $62.5 \mathrm{kgf}(612.9 \mathrm{~N})$. Hardness measurements were made on the rubbing surface of the samples. Since the dimensions of the samples are $\varnothing 25.4 \times 9 \mathrm{~mm}$, the values were calculated from the middle and close points of the surface. The arithmetic mean of three sample results with the same content for each sample was taken. The density measurements of the samples were determined in water by Archimedes principle.

\section{Results and Discussion}

Two different composite brake linings containing $10 \%$ nano and micro borax by mass were produced provided that the other materials that make up the lining composition remained constant. In the experiments, the arithmetic average of the results obtained from 5 experimental samples with the same content was taken. The time dependent friction coefficient plots of the samples are shown in 
When the graphs are examined, the average lowest friction co-

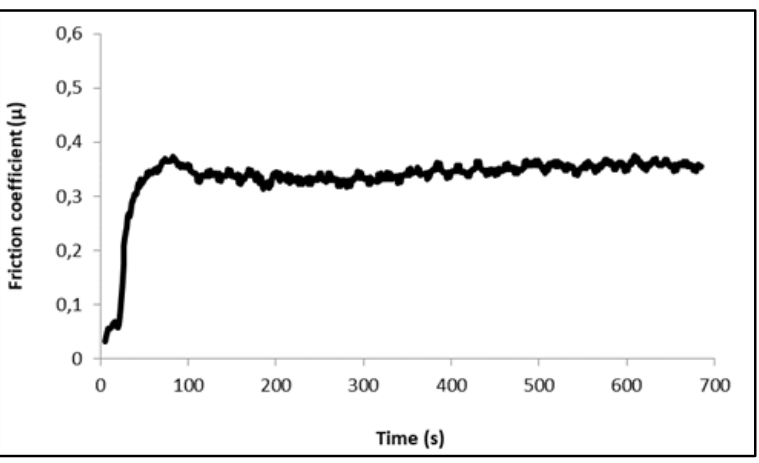

Figure 3 and Figure 4.

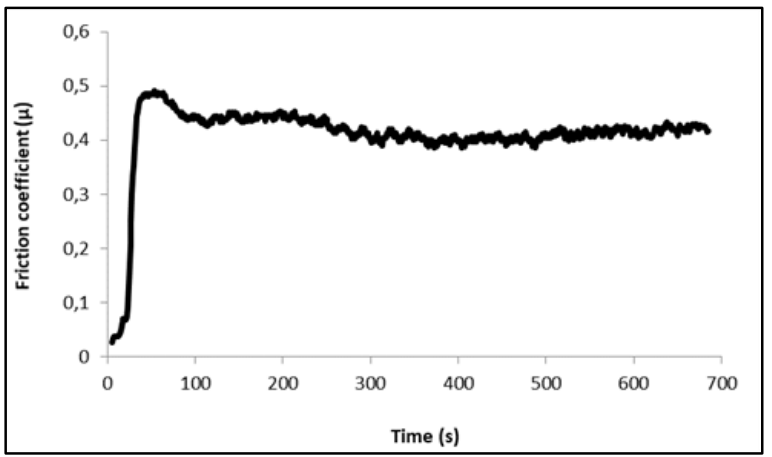

Fig. 3. Friction coefficient graph of lining containing $10 \%$ micro borax (MB10) by mass

Fig. 4. Friction coefficient graph of lining containing $10 \%$ nano borax (NB10) by mass

Figure 3 shows the friction coefficient change of the sample coded MB10 containing $10 \%$ micro borax by mass, depending on time. The temperature occurring at the interface between the lining and the disc was measured as $37^{\circ} \mathrm{C}$ at the lowest and $127^{\circ} \mathrm{C}$ at the highest. The average friction coefficient value is 0.33 and the friction stability is $76 \%$. Figure 4 shows the change in the friction coefficient of the sample coded NB10 containing $10 \%$ nano borax by mass depending on time. The temperature occurring between the lining and the disc interface is $21^{\circ} \mathrm{C}$ at the lowest and $102{ }^{\circ} \mathrm{C}$ at the highest. Average friction coefficient value is 0.42 and friction stability is $85 \%$. Ostermeyer [11] stated in his study on the dynamics of the friction coefficient that the friction coefficient will decrease due to the increase in the interface temperature.

When the graphs are examined, there is a continuous fluctuating change in the form of a slight decrease in the friction coefficient. Anderson [12] stated that this was due to the periodic continual variation of temperature into the contact areas on the disc surface during friction. Due to this effect, a continuous change occurs in the friction coefficient. In addition, Stachowiak and Batchelor [13] explain this situation by the coalescence and growth of the roughness on the surface of the friction pairs. In this case, an adhesion and a release state are constantly repeated, causing a continuous increase and decrease in the friction coefficient. efficient of 0.33 gave the sample with MB10 code containing $10 \%$ micro borax by mass. The average maximum friction coefficient of 0.42 gave the sample coded NB10 containing $10 \%$ nano borax by mass. One of the most important features required from brake linings is that the change in the friction coefficient is at a minimum level due to the increase in the interface temperature caused by friction during braking $[14,15]$. The friction stability $(\%)$ value should be as high as possible and close to 100 , and the slope and fluctuations of the obtained curve should be minimum [16].

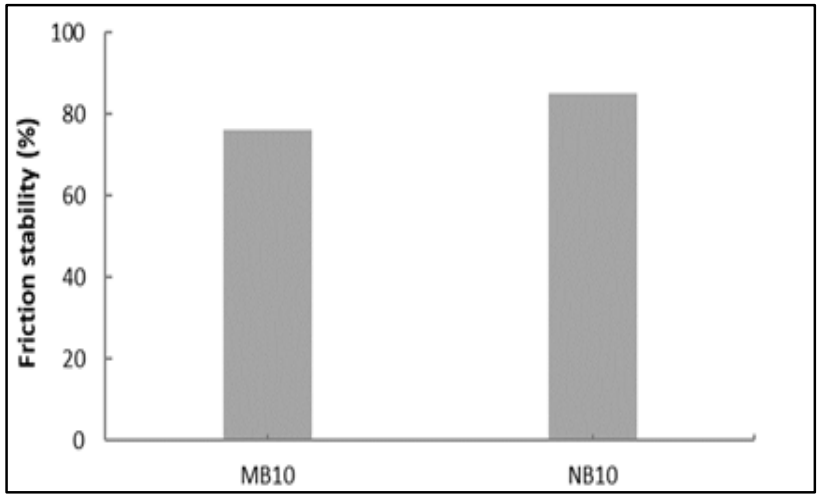

Fig. 5. Friction stability of samples containing borax (\%)

When the friction test results were examined, it was seen that the temperature occurring at the interface between the lining and the disc directly affected the friction stability. High friction stability is required in brake lining materials. The highest friction stability value was seen in the sample containing $10 \%$ nano borax by mass (Figure 5).

Table 2. Typical characteristics of the brake lining with borax.

\begin{tabular}{c|c|c}
\hline Sample & MB10 & NB10 \\
\hline Average coefficient of friction $\left(\mu_{\text {ort }}\right)$ & 0.33 & 0.42 \\
\hline Specific wear rate $\left(\mathrm{cm}^{3} / \mathrm{Nm}\right)$ & $1.83 \times 10^{-6}$ & $1.93 \times 10^{-6}$ \\
\hline Brinell hardness $(\mathrm{HB})$ & 30 & 34 \\
\hline Density $\left(\mathrm{g} / \mathrm{cm}^{3}\right)$ & 2.01 & 2.23
\end{tabular}

Physical properties such as friction properties and hardness and density of the samples containing nano borax are given in Table 2 . Accordingly, it was observed that the average friction coefficient values of the samples with high hardness were also higher. However, the high hardness in the linings may cause more wear on the counter element brake disc.

After the braking test, the microstructures (SEM) of the friction surface of the linings are shown in Figure 6. On the micro and macro scale, the wear and friction characteristics of disc/brake lining depend on the formation, shape adaptation, disintegration of contact plateaus and growth, and thermal-induced deformation [17-19]. The process of the friction plateau formation in friction materials is complicated and depends on the thermal history of sliding interface. In the case of normal braking applications, it is 
known that the fibrous materials, organic constituents, and solid lubricants play important roles in establishing the transfer layer at the friction interface and this transfer layer become significant and more effective at higher pressure [20]. The more homogeneous microstructure is noticed in nano borax specimen. It is also seen from these figures that larger micro-voids occurred in the samples. When the figure showing the microstructure of the sample containing micro borax is examined, macro voids are seen. However, when the figure showing the microstructure of the sample containing nano borax is examined, smaller and less micro-voids are seen.
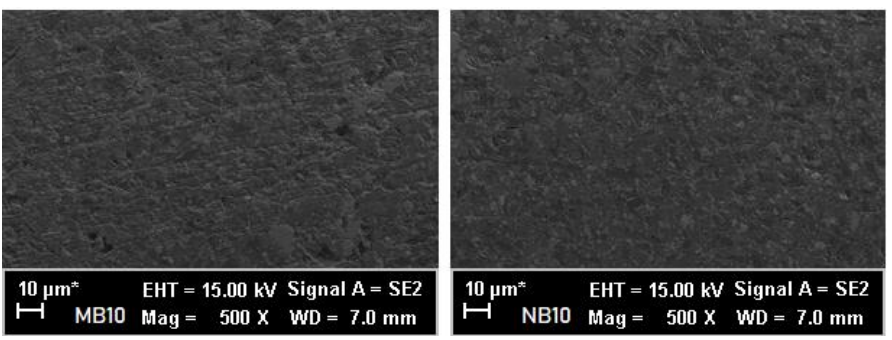

Fig. 6. SEM morphologies of MB10 and NB10 coded samples frictional surface

\section{Conclusions}

In this study, the tribological properties of micro and nano sized borax material, which can withstand high temperatures caused by friction and can be used as friction material, were investigated. The results of this research are summarized as follows:

- Nano borax containing lining positively affected the frictional stability.

- It has been observed that the temperature occurring at the interface between the lining and the disc directly affects the friction stability.

- Micro borax containing lining has decreased the friction coefficient due to the increase in the interface temperature.

- The use of nano borax in lining has increased the friction coefficient.

- Macro voids were observed in the lining with micro borax content. This has affected the friction layer.

- A homogeneous microstructure is observed in the nano borax sample.

\section{Conflict of Interest Statement}

The authors declare that there is no conflict of interest in the study.

\section{CRediT Author Statement}

İlker Sugözü: Conceptualization, Supervision, Writing - original draft,

Banu Sugözü: Writing-original draft, Resources

\section{References}

[1] Jeganmohan S, Sugozu B. Usage of powder pinus brutia cone and colemanite combination in brake friction composites as friction modifier. Mater Today-Proc. 2020; 27:2072-2075.
[2] Reinsch EW. Sintered metal brake linings for automotive applications. In Perspectives in Powder Metallurgy Fundamentals, Methods, and Applications. Springer, Boston, MA. 1970; 9-21.

[3] Gediktaş M. Sürtünme malzemelerinin deneysel tayini, İstanbul Teknik Üniversitesi Matbaası, Gümüşsuyu, İstanbul. 1968.

[4] Sugözü İ. Bor Katkılı Asbetsiz Otomotiv Fren Balatası Üretimi ve Frenleme Karakteristiğinin İncelenmesi. Mech Eng. 2009;277.

[5] Başar G, Buldum BB, Sugözü İ. Kolemanit ve Boraks Takviyeli Fren Balatalarının Sürtünme Performansı. El-Cezeri J Sci Eng. 2018;5(2): 635-644.

[6] Akıncıoğlu G, Öktem H, Uygur I, Akıncıoğlu S. Determination of friction-wear performance and properties of eco-friendly brake pads reinforced with hazelnut shell and boron dusts. Arab J Sci Eng. 2018;43(9): 4727-4737.

[7] Akıncıoğlu G, Uygur İ, Öktem H, Akıncıoğlu S. The effects of boron oxide powders on the tribological properties of brake pads. Sakarya Uni J Sci. 2018;22(2): 755-760.

[8] Akıncıoğlu G, Akıncıoğlu S, Uygur İ, Öktem H. Investigation of the effect of boron oxide on the friction behavior of brake pads as an alternative additive. J Boron. 2019;4(1): 1-6.

[9] Sugözü I. Investigation of using rice husk dust and ulexite in automotive brake pads. Mater Test. 2015;57(10): 877-882

[10]TSE 555. Highway Vehicles-Brake System-Brake Pads for Friction Brake. Turkish Standard Institute. Ankara, Turkey. 1992.

[11]Ostermeyer GP. On the dynamics of the friction coefficient. Wear. 2003;254: 852-858.

[12]Anderson AE. Friction and Wear of Automotive Brakes, USA, Friction, Lubrication and Wear Technology ASM Handbook. 1992.

[13]Stachowiak GW, Batchelor AW. Adhesion and adhesive wear, In: Engineering Tribology, Eds, A.B.D: Butterworth-Heinemann, 2001;533-553.

[14]Persson BNJ. Theory of Friction - the Role of Elasticity in Boundary Lubrication. Phys Rev B, 1994;50 (7):4771-4786.

[15]Tabor D. Friction as a dissipated process, Friction of organic polymers in fundamentals of friction. Macroscopic and Microscopik Processes, 1996;3:220.

[16]Bijwe J, Aranganathan N, Sharma S, Dureja N, Kumar, R. Nanoabrasives in friction materials-influence on tribological properties. Wear. 2012;296:693-701.

[17]El-Tayeb NSM, Liew KW. On the dry and wet sliding performance of potentially new frictional brake pad materials for automotive industry. Wear. 2009;266:275-287.

[18]Eriksson M, Bergman F, Jacobson S. On the nature of tribological contact in automotive brakes. Wear. 2002;252:26-36.

[19]Sugozu B. Tribological properties of brake friction materials containing fly ash. Ind Lubr Tribol. 2018;70: 902-906.

[20]Kim SJ, Jang H. Friction and wear of friction materials containing two different phenolic resins reinforced with aramid pulp. Tribol Int. 2000;33:477-484. 